\title{
Redaksioneel tot die P.M. Venter Huldigingsbundel
}

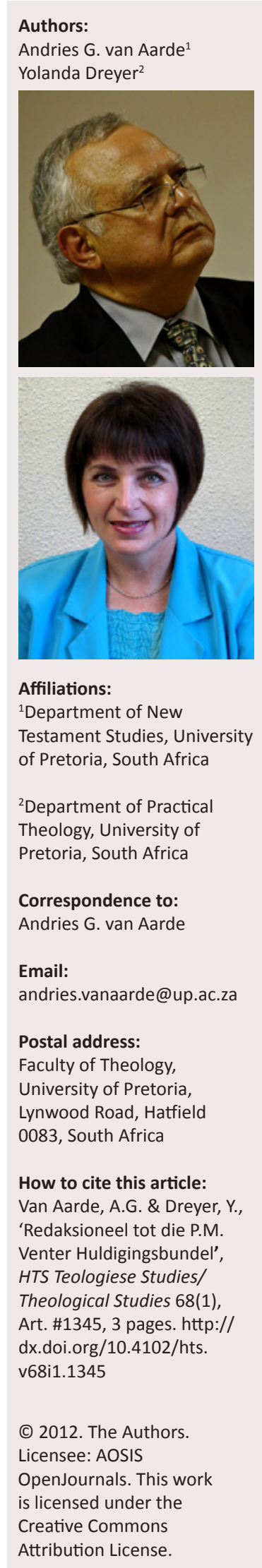

\section{Ter erkenning van Pieter M. Venter}

Hierdie huldigingsbundel word aan professor Pieter Venter opgedra vir sy toegewyde diens aan die Ou-Testamentiese Wetenskap. Professor Venter het in 2012 geëmeriteer.

Nadat Pieter Venter die graad BA Honneurs in Semitiese tale (1969) en die graad BD in Teologie (1971 met lof) aan die Universiteit van Pretoria behaal het, skryf hy in 1974 in vir deeltydse studie met die oog op die graad DD. In sy tweede BD-jaar word die Nico Prinsloo prys vir Ou-Testamentiese Wetenskap aan hom toegeken. Hy lê die vereiste DD-eksamens af in die vakgebiede van Ou-Testamentiese Wetenskap, Nuwe-Testamentiese Wetenskap en Godsdienswetenskap (1979). Hy voltooi sy proefskrif oor Spreuke 1-9 met die titel 'Spreuke, Wysheid en Lewe' en ontvang die DD-graad in 1981 van die Universiteit van Pretoria. In die proefskrif ondersoek hy die probleem dat die Wysheidsliteratuur aanvanklik nie in Ou-Testamentiese teologie 'n plek gevind het nie en ook net gedeeltelik in die kanon van die Bybel ingesluit is. Wysheidsperspektiewe is tradisioneel nie in Ou-Testamentiese teologiese modelle ingesluit nie. Tussen 1984 en 1987 publiseer professor Venter vier artikels oor Spreuke. Die versameling Spreuke 1-9 is van die jongste materiaal in die Judees-Christelike Bybel. Daarom fokus sy navorsing op die geskiedenis van kanonvorming. Die ondersoek sluit geskrifte uit die Tweede Tempel tydperk (515 v.C. - 70 n.C.) in. Hierdie geskrifte en in die besonder die boeke van die derde gedeelte van die $\mathrm{Ou}$ Testament, 'die Geskrifte', word die fokus van sy navorsing. Die eerste fase van sy navorsing het oor literatuur uit die vroeë Tweede Tempel tydperk (die sesde en vyfde eeu v.C.) gegaan en drie artikels oor EsraNehemia het die lig gesien. Die boek Daniël uit die tweede eeu v.C. is een van die jongste boeke in die Ou-Testamentiese kanon. Derhalwe verskuif die fokus van Venter se navorsing na die tweede en derde eeu van die latere Tweede Tempel tydperk om die boek Daniël te dek, asook kontemporêre literatuur wat nie deel van die kanon was en ook nie in die Masoretiese Hebreeuse Bybel ingesluit is nie. In 10 artikels oor kanonisiteit ondersoek

\section{In honour of Pieter M. Venter}

This dedication honours Professor Pieter Venter for his contribution to Old Testament studies. Professor Venter retired in 2012.

He obtained the degree BA Honours in Semitic languages (1969) and the degree BD in Theology (1971 with distinction) from the University of Pretoria. He received the Nico Prinsloo award for Old Testament Studies in his second BD year. In 1974 he registered for part-time doctoral studies. He completed his comprehensive examinations in the fields of Old Testament Studies, New Testament Studies and Science of Religion in 1979. His DD thesis, titled 'Proverbs, Wisdom and Life' was on Proverbs 1-9. The University of Pretoria conferred the degree on him in 1981. His thesis addressed the problem that Wisdom literature was initially ignored by Old Testament theology and only partially included in the biblical canon. Subsequently, sapient perspectives were traditionally not included in Old Testament theological models. Between 1984 and 1987 Professor Venter published four articles on Proverbs. Because the collection of material in Proverbs 1-9 forms part of the later writings included in the Judeo-Christian Bible, his research focused on the history of canon formation. This investigation included writings that originated during the Second Temple period (515 BCE - $70 \mathrm{CE}$ ). These writings, and especially the books of the third section of the canonical Old Testament called 'the Writings', became the focus of his research interest. The first phase of his research was on literature from the earlier stages of the Second Temple period (the 6th and 5th centuries BCE) and he published three articles on Ezra-Nehemiah. The book of Daniel, from the 2nd century BCE, is one of the latest books included in the biblical canon. Venter's research shifted to the third and second centuries of the later Second Temple period to include the book of Daniel and contemporary literature that was not part of the canon and was also not included in the Masoretic Hebrew Bible. He investigated the process of the inclusion and exclusion of material in the biblical canon in 10 articles 
hy die proses waardeur Bybelse materiaal in of uit die kanon gesluit is, asook die probleme wat met hierdie proses verband hou. Meer onlangs publiseer professsor Venter 11 artikels oor die boek Daniël, asook 10 artikels oor die apokriewe en pseudepigrafiese literatuur. Met sy werk oor die boek Daniël en literatuur uit die Tweede Tempel tydperk maak hy 'n bydrae tot plaaslike en internasionale kongresse waar hy voordragte lewer oor die boek Daniël asook die apokriewe of pseudepigrafiese literatuur. Hy hou lesings oor Daniël by kongresse van die Society of Biblical Literature (SBL) in Münster in 1993, in San Antonia in 2004, in Rome in 2009, by 'n byeenkoms van die International Organization for the Study of the Old Testament in Basel in 2001 en by die Colloquium Biblicum Lovaniensis in Leuven in 2002. In Suid-Afrika lewer hy verskeie voordragte oor Daniël tydens byeenkomste van die Ou-Testamentiese Werkgemeenskap van SuidAfrika. In 2012, die jaar waarin hy uittree as Professor in Ou-Testamentiese Wetenskap en Departementshoof van Ou-Testamentiese Wetenskap, word Pieter Venter deur die Nasionale Navorsingstigting van Suid-Afrika gegradeer. Die navorsingsuitsette wat hierdie gradering tot gevolg gehad het word in die bylaag hieronder gelys.

Prof. Dr A.G. van Aarde

Redakteur: HTS Teologiese Studies

Prof. Dr Y. Dreyer

Mede-redakteur: HTS Teologiese Studies and the problems arising from this enterprise. More recently Professor Venter published 11 articles on the book of Daniel and 10 articles on apocryphal and pseudepigraphic literature. Venter contributed to local and international conferences with his work on the book of Daniel and Second Temple literature, where he presented papers on the book of Daniel and apocryphal or pseudepigraphic literature. He read papers on Daniel at conferences of the Society of Biblical Literature in Munster in 1993, in San Antonia in 2004 and in Rome in 2009, at a meeting of the International Organization for the Study of the Old Testament in Basel in 2001 and at the Colloquium Biblicum Lovaniensis in Leuven in 2002. In South Africa he read several papers on Daniel at meetings of the Old Testament Society of South Africa. In 2012, the year of his retirement as Professor of Old Testament Studies and Head of the Department of Old Testament Studies, Pieter Venter received scholarly rating from the National Research Foundation of South Africa. The research output that contributed to his rating is listed in the appendix below.

Prof. Dr A.G. van Aarde

Editor: HTS Theological Studies

Prof. Dr Y. Dreyer

Associate editor: HTS Theological Studies 


\section{Bylaag 1 / Appendix 1 Wetenskaplike publikasies / Scientific publications}

\section{Hoofstukke in boeke / Chapters in books}

2004, 'Spatiality in Psalm 29', in D.J. Human \& C.J.A. Vos (eds.), Psalms and liturgy, pp. 235-250, T\&T Clark, London.

2007, 'Synchrony and diachrony in apocalyptic studies', in J. Le Roux \& E. Otto (eds.), South African perspectives on the Pentateuch between synchrony and diachrony, $\mathrm{pp}$. 185-196, T\&T Clark, London. (Library of Hebrew Bible/ Old Testament Studies 463).

\section{Artikels in portuurgeëvalueerde akademiese tydskrifte / Refereed/peer-reviewed articles in journals}

2011, 'Congruent ethos in the Second Temple literature of the Old Testament', HTS Teologiese Studies/Theological Studies 67(1), Art. \#965, 13 pages. http://dx.doi. org/10.4102/hts.v67i1.965

2011, 'The function of the Ammonite Achior in the book of Judith', HTS Teologiese Studies/Theological Studies 67(3), Art. \#1101, 9 pages. http://x.doi.org/10.4102/hts. v67i3.1101

2010, 'A triadic construct in Jubilees 30', HTS Teologiese Studies/Theological Studies 66(1), Art. \#801, 8 pages. http://dx.doi.org/10.4102/hts.v66i1.80

2009, 'Canon, intertextuality and history in Nehemiah 7:72b-10:40', HTS Teologiese Studies/Theological Studies 65(1), Art. \#135, 8 pages. http://dx.doi.org/10.4102/hts. v65i1.135

2009, 'Inklusivisme en eksklusivisme: 'n Studie van twee tendense', HTS Teologiese Studies/Theological Studies 65(1), Art. \#314, 10 pages. http://dx.doi.org/10.4102/hts. v65i1.314

2008, 'Space, time and group identity in Jubilees 8-9', HTS Teologiese Studies/ Theological Studies 64(1), 631-650.

2007, 'Die huwelik as identiteitsmerker in die Ou Testament', HTS Teologiese Studies/ Theological Studies 63(3), 1213-1237.

2007, 'Intertextuality in the Book of Jubilees', HTS Teologiese Studies/Theological Studies 63(2), 463-480.

2006, 'A study of space in Daniel 1', Old Testament Essays 19(3), 993-1004.

2006, 'Doomsday movements in Africa: Restoration of the Ten Commandments', HTS Teologiese Studies/Theological Studies 62(1), 155-173.

2006, 'Kanon: Eenheid en diversiteit', HTS Teologiese Studies/Theological Studies 62(4), 1369-1393.

2005, 'Atonement through blood in Leviticus', Verbum et Ecclesia 26(1), 275-292.

2005, 'Die skuldgebed in Esra 9:6-15', HTS Teologiese Studies/Theological Studies $61(1 / 2), 545-563$

2005, 'Jews and Christians', HTS Teologiese Studies/Theological Studies 61(3) 953-971.
2005, 'Penitential prayer in the books of Baruch and Daniel', Old Testament Essays 18(2), 406-425.

2005, 'The translation of Psalm 89:13 and its implications', HTS Teologiese Studies/ Theological Studies 61(1/2), 531-544.

2004, 'Constitualised space in Daniel 9', HTS Teologiese Studies/Theological Studies $60(1 / 2), 607-624$.

2004, 'Psalm 89 and Daniel 7', Old Testament Essays 17(4), 678-691.

2004, 'Reviewing history in apocalyptic literature as ideological strategy', HTS Teologiese Studies/Theological Studies 60(3), 703-723.

Portuurgeëvalueerde kongresbydraes / Refereed/peerreviewed conference proceedings

2007, 'Daniel 9: A penitential prayer in apocalyptic garb', in M.J. Boda, D.K. Falk \& R.A. Werline (eds.), Seeking the favor of God, Volume 2: The development of penitentia prayer in Second Temple Judaism, pp. 33-49, Society of Biblical Literature, Atlanta, GA. (SBLEJL)

2007, 'Spatiality in the second parable of Enoch', in G. Boccaccini (ed.), Enoch and the Messiah Son of Man: Revisiting the Book of Parables, pp. 403-412, Eerdmans, Grand Rapids, MI.

2003, 'Spatiality in Enoch's journeys (1 Enoch 12-36)', in F. Garcia Martinez (ed.), Wisdom and apocalypticism in the Dead Sea scrolls and in the biblical tradition, pp. 211-230, Peeters-Leuven University Press, Leuven. (Bibliotheca Ephemeridum Theologicae Lovaniensum CLXVIII).

\section{Ander akademiese erkende navorsingsuitsette / Other recognised research output}

2003, 'Historical review in the Damascus Document', Verbum et Ecclesia 24(2), 598-622.

2003, 'Northern traditions in second century BCE literature', Old Testament Essays $16(2), 464-488$.

2003, 'Zechariah 10:10 and a northern tradition', Old Testament Essays 16(3), 746-757.

2002, 'Die makro sosiale ruimte van die Boek van die Wagte (1 Henog 1-36)', HTS Teologiese Studies/Theological Studies 58(4), 1513-1536.

2002, 'The connection between wisdom literature, apocalypses and canon', Old Testament Essays 15(2), 470-488.

2001, 'Violence and non-violence in Daniel', Old Testament Essays 14(2), 311-329.

2000, 'Die funksie van ruimte in die reisverhale in 1 Henog 12-36', HTS Teologiese Studies/Theological Studies 56(1), 38-62.

1999, 'Understanding the concept of “time" in Daniel', Skrif en Kerk 21(3), 666-681.

1997, 'Daniel and Enoch: Two different reactions', HTS Teologiese Studies/Theological Studies 53(1/2), 68-91. 